\title{
QUALITY CHARACTERIZATION OF BANANA VARIETIES GROWN UNDER WEST BENGAL CONDITIONS
}

\author{
VENKATA SATISH KUCHI ${ }^{1}$, J. KABIR ${ }^{2}$, F. K. BOURI ${ }^{3}$, RAJESH GUPTA ${ }^{\mathbf{4}} \&$ R. S. DHUA ${ }^{\mathbf{5}}$ \\ ${ }^{l}$ Department of Postharvest Technology, College of Horticulture, YSRHU, Anantharajupeta, Andhra Pradesh, India \\ ${ }^{2,5}$ Department of Postharvest Technology, BCKV, Nadia, West Bengal, India \\ ${ }^{3}$ Department of Fruits and Orchard Management, BCKV, Nadia, West Bengal, India \\ ${ }^{4}$ Scientist, Krishi Vigyan Kendra, RVSKVV, Gwalior, Madhya Pradesh, India
}

\begin{abstract}
The most extensively cultivated crops all over the world to meet the hunger of poor people is banana. It is highly nutritive and every part of the plant is useful. Six different varieties of banana viz. Grand Naine (AAA), Poyo $(A A A)$, Kalyani Local (ABB), Nendran (AAB), Cooking I (ABB) and Champa $(A A B)$ were selected for the study. Fully mature hard green banana fruits (Figure 1) of selected varieties were harvested from farm maintained by AICRP on tropical fruits Mandoli, Nadia. Different physical parameters such as fruit weight, fruit length, fruit thickness, pulp weight, pulp thickness, peel weight, peel thickness, pulp peel ratio and ease of peeling and total soluble solids were recorded during the experiment. Fruit weight, peel weight, pulp weight and pulp thickness were recorded to be maximized in Kalyani Local $\left(V_{3}\right)$ and minimum in Poyo $\left(V_{2}\right)$ and it varied from $92.20 \mathrm{~g}$ to $135.90 \mathrm{~g}$ for fruit weight, $39.63 \mathrm{~g}$ to $81.53 \mathrm{~g}$ for peel weight, 52.57 to $108.80 \mathrm{~g}$ for pulp weight and 2.50 to $3.77 \mathrm{~cm}$ for pulp thickness respectively. Fruit length was maximum $(23.93 \mathrm{~cm})$ in Nendran $\left(V_{4}\right)$. TSS was estimated to be maximized in Poyo $\left(V_{2}\right)\left(4.27^{\circ}\right.$ Brix).

KEYWORDS: Banana, Varieties, Total Soluble Solids \& Physical Parameters
\end{abstract}

Received: Apr 12, 2017; Accepted: May 13, 2017; Published: May 25, 2017; Paper Id.: IJASRJUN201732

\section{INTRODUCTION}

The banana is one of the oldest fruits known to mankind. It is one of the widely grown and consumed fruits due to their distinct aroma and taste, in all parts of the world. It is highly nutritive and every part of the plant is useful. For these reasons it is often referred as 'Apple of Paradise' and 'Tree of paradise'. It is a good source of vitamin $\mathrm{A}, \mathrm{C}$ and $\mathrm{B}_{2}$. Fruits are a rich source of minerals like magnesium, sodium, potassium, phosphorous, calcium and iron. The ripe fruits are delicious and are used for table purpose. Many products are made from banana such as banana chips, figure, soft drink, flour and jam. Raw banana can be used for flour preparation and fruits that are ripe used in making of powder.

India is the largest producer of banana in the world. In West Bengal, banana is cultivated in an area of 45,500 ha with a production of 1.09 million tonnes for the year 2013-14 (Anonymous, 2015). Moreover, with increasing population and urbanization leading to the conversion of agricultural land into industrial areas, it is hardly possible to make an increase in area under cultivation. Instead, if we minimize the post harvest losses, automatically there will be an increase in production. However, this high production will have significance only when it reaches consumers in good condition. Faulty handling practices coupled with underdeveloped and exploitive marketing systems results in postharvest losses to the extent of about $30 \%$ and value deterioration, 
leaving little quality surpluses for export and processing (Anonymous, 2002). Different types of unexploited cultivars grown in this region are not evaluated. Therefore, keeping these points in view a plan of research on "Quality characterization of banana varieties grown under West Bengal conditions" was undertaken.

\section{MATERIALS AND METHODS}

The present study on "Quality characterization of banana varieties grown under West Bengal conditions" was carried out in the department of Postharvest Technology of Horticultural Crops, Bidhan Chandra Krishi Viswavidyalaya Mohanpur, Nadia, West Bengal during 2012-2015. The study comprises six different six varieties, namely Grand Naine (AAA), Poyo (AAA), Kalyani Local (ABB), Nendran (AAB), Cooking I (ABB) and Champa (AAB). Fully mature hard green banana fruits (Figure 1) of selected varieties were harvested from farm maintained by AICRP on tropical fruits Mandoli, Nadia.

\section{Observations}

Different physical parameters such as fruit weight, fruit length, fruit thickness, pulp weight, pulp thickness, peel weight, peel thickness, pulp peel ratio and ease of peeling were recorded during the experiment. Parameters such as Total Soluble Solids (TSS) were also analyzed.

\section{Statistical Design}

The data obtained from the three replications were subjected to the analysis of variance by ' $F$ ' test for Completely Randomized Design (CRD) for parameters of fresh fruits (Gomez and Gomez, 1984).

\section{Details of Observations}

Physical parameters were analyzed by taking ten fruits from sample from the methodology suggested by Dodge and Orchard (1997). Thickness of the finger was measured with the help of vernier calipers. Flexible meter was used to calculate the finger length. Hand peeling was employed to separate peel from fruit pulp and with the help of digital weighing machine they were weighed separately to obtain the weight of individual fruit, peel and pulp. The weight of the pulp was divided by peel weight to determine the pulp peel ratio. A a 5- point hedonic scale was employed to establish the ease or difficulty to peel (Belayneh et al., 2013). Total soluble solids were measured with the help of hand refractometer as method suggested by Dodge and Orchard 1997; Tigist et al., 2013 and Kundan et al. 2011.

\section{RESULTS AND DISCUSSIONS}

Fruit characters of six varieties (i.e. $\mathrm{V}_{1}$ : Grand Maine, $\mathrm{V}_{2}$ :Poyo, $\mathrm{V}_{3}$ :Kalyani Local, $\mathrm{V}_{4}$ :Nendran, $\mathrm{V}_{5}$ :Cooking I and $\mathrm{V}_{6}$ :Champa) has been presented in Table 1 . There were significant differences in fruit and pulp characters among the varieties. Fruit weight, peel weight, pulp weight and pulp thickness were recorded to be maximized in Kalyani Local $\left(\mathrm{V}_{3}\right)$ and minimum in Poyo $\left(\mathrm{V}_{2}\right)$ and it varied from $92.20 \mathrm{~g}$ to $135.90 \mathrm{~g}$ for fruit weight, $39.63 \mathrm{~g}$ to $81.53 \mathrm{~g}$ for peel weight, 52.57 to $108.80 \mathrm{~g}$ for pulp weight and 2.50 to $3.77 \mathrm{~cm}$ for pulp thickness respectively. Fruit length was maximum (23.93 $\mathrm{cm})$ in Nendran $\left(\mathrm{V}_{4}\right)$ and minimum (15.40) in Poyo $\left(\mathrm{V}_{4}\right)$ while the maximum fruit diameter $(4.25 \mathrm{~cm})$ was observed in Champa $\left(\mathrm{V}_{6}\right)$ and minimum $(2.80 \mathrm{~cm})$ in Poyo $\left(\mathrm{V}_{2}\right)$. Pulp to peel ratio was observed to be significantly higher in $\mathrm{V}_{4}$ i.e. 'Nendran' than $\mathrm{V}_{2}, \mathrm{~V}_{3}, \mathrm{~V}_{5}$ and $\mathrm{V}_{6}$. However, it was on par with $\mathrm{V}_{1}$. Peel thickness in $\mathrm{V}_{4}$ i.e. Nendran was noted to be significantly $(\mathrm{P} \leq 0.05)$ lower than $\mathrm{V}_{1}, \mathrm{~V}_{3}, \mathrm{~V}_{5}$ and $\mathrm{V}_{6}$ but it was at par with $\mathrm{V}_{2}$. 
Table 1: Different Physical Characteristics of Banana Varieties for Preparation of Chips

\begin{tabular}{|c|c|c|c|c|c|c|}
\hline Treatments & $\begin{array}{c}\text { Fruit Weight } \\
(\mathbf{G})\end{array}$ & $\begin{array}{c}\text { Fruit Length } \\
(\mathbf{C m})\end{array}$ & $\begin{array}{c}\text { Fruit Thickness } \\
(\mathbf{C m})\end{array}$ & $\begin{array}{c}\text { Pulp } \\
\text { Weight }(\mathbf{G})\end{array}$ & $\begin{array}{c}\text { Pulp Thickness } \\
(\mathbf{C m})\end{array}$ & $\begin{array}{c}\text { Peel } \\
\text { Weight }(\mathbf{G})\end{array}$ \\
\hline $\mathbf{V}_{\mathbf{1}}$ & 146.23 & 19.13 & 3.50 & 89.77 & 3.07 & 56.47 \\
\hline $\mathbf{V}_{\mathbf{2}}$ & 92.20 & 15.40 & 2.80 & 52.57 & 2.50 & 39.63 \\
\hline $\mathbf{V}_{\mathbf{3}}$ & 190.33 & 20.33 & 4.23 & 108.80 & 3.77 & 81.53 \\
\hline $\mathbf{V}_{\mathbf{4}}$ & 135.90 & 23.93 & 3.09 & 85.03 & 2.80 & 50.87 \\
\hline $\mathbf{V}_{\mathbf{5}}$ & 164.13 & 18.30 & 4.02 & 99.37 & 3.50 & 64.77 \\
\hline $\mathbf{V}_{\mathbf{6}}$ & 154.83 & 16.83 & 4.25 & 83.83 & 3.60 & 71.00 \\
\hline $\mathbf{S E}(\mathbf{m})$ & 4.32 & 0.76 & 0.13 & 2.77 & 0.10 & 1.84 \\
\hline $\mathbf{C D}_{\mathbf{0 . 0 5}}$ & 13.47 & 2.37 & 0.40 & 8.62 & 0.31 & 5.73 \\
\hline
\end{tabular}

$\mathrm{V}_{1}$ (Grand Naine); $\mathrm{V}_{2}$ (Poyo); $\mathrm{V}_{3}$ (Kalyani local); $\mathrm{V}_{4}$ (Nendran); $\mathrm{V}_{5}$ (Cooking I); $\mathrm{V}_{6}$ (Champa)

Ease of peeling which was assessed subjectively indicated that the score of $\mathrm{V}_{2}$ i.e. Poyo was highest (3.43) (Easy is peeling), while the score of $\mathrm{V}_{4}$ i.e. Nendran was last (1.08) (very difficult to peel). The data revealed that, except Poyo i.e. $V_{2}$, all the other varieties were difficult to peel (scores between 1- 3). TSS was estimated to be maximized in $V_{2}(4.27$ ${ }^{\circ}$ Brix $)$ followed by $\mathrm{V}_{1}\left(2.53{ }^{\circ}\right.$ Brix $), \mathrm{V}_{6}\left(2.33^{\circ}\right.$ Brix $) \mathrm{V}_{4}\left(2.00{ }^{\circ}\right.$ Brix $) \mathrm{V}_{3}\left(1.93{ }^{\circ}\right.$ Brix $)$ and $\mathrm{V}_{5}\left(1.87{ }^{\circ}\right.$ Brix $)$ in that decreasing order (Table 2).

Table 2: Different Physical Characteristics and TSS of Banana Varieties for Preparation of Chips

\begin{tabular}{|c|c|c|c|c|}
\hline Treatments & Peel Thickness (cm) & Pulp Peel Ratio & Ease of Peeling & TSS $\left({ }^{\circ}\right.$ Brix) \\
\hline $\mathbf{V}_{\mathbf{1}}$ & 0.43 & 1.59 & 2.16 & 2.53 \\
\hline $\mathbf{V}_{\mathbf{2}}$ & 0.30 & 1.33 & 3.43 & 4.27 \\
\hline $\mathbf{V}_{\mathbf{3}}$ & 0.46 & 1.34 & 1.13 & 1.93 \\
\hline $\mathbf{V}_{\mathbf{4}}$ & 0.29 & 1.67 & 1.08 & 2.00 \\
\hline $\mathbf{V}_{\mathbf{5}}$ & 0.52 & 1.54 & 2.38 & 1.87 \\
\hline $\mathbf{V}_{\mathbf{6}}$ & 0.65 & 1.18 & 2.50 & 2.33 \\
\hline $\mathbf{S E}(\mathbf{m})$ & 0.03 & 0.03 & 0.41 & 0.17 \\
\hline \multicolumn{2}{|c|}{$\mathbf{C D}_{\mathbf{0 . 0 5}}$} & 0.09 & 1.28 & 0.54 \\
\hline
\end{tabular}

Results indicate that the variety Grand Maine, Kalyani Local, Nendran, Cooking I and Champa have a thick pulp when compared with the mean pulp thickness of Poyo. Among these varieties Nendran had the thinnest peel and high pulp: peel ratio than the other four varieties. Consumers often prefer thicker and bulkier pulp (Dadzie and Orchard 1997; Forster et al., 2003; Muchui et al., 2010). This confirms the potentiality of Nendran to produce larger sized slices for processing into various products such as chips. The pulp thickness of Nendran was, however lesser than Grand Maine, Kalyani Local, Cooking I and Champa. Moreover, these varieties were superior to Nendran for most of the physical properties like fruit weight, fruit length, pulp weight etc. The pulp size of cv. Poyo was least among selected varieties. 

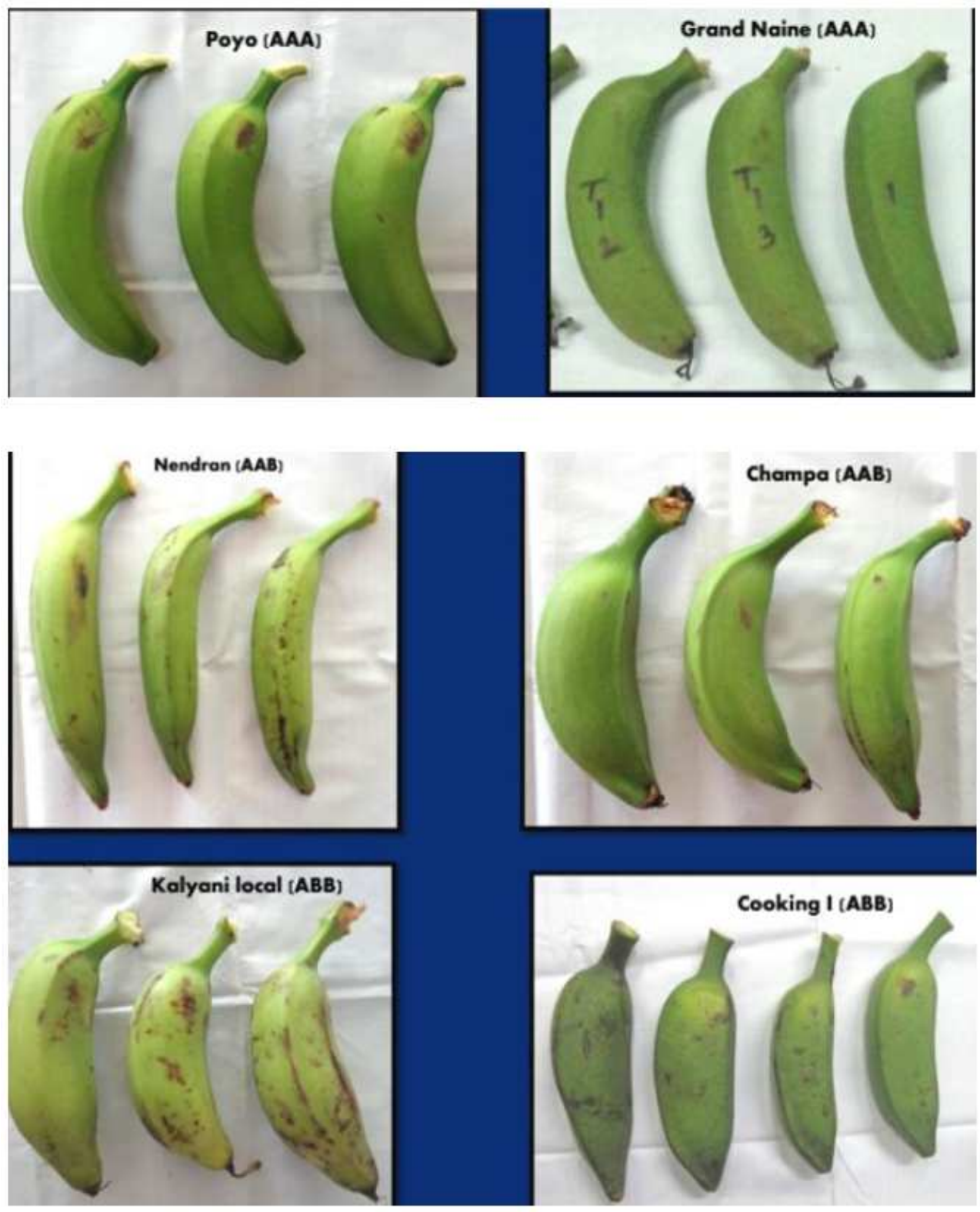

Figure 1: Mature Green Hard Stage of Different Varieties Selected for Chips Making

\section{CONCLUSIONS}

In conclusion, fruit weight, peel weight, pulp weight and pulp thickness were recorded to be maximized in Kalyani Local $\left(\mathrm{V}_{3}\right)$ and minimum in Poyo $\left(\mathrm{V}_{2}\right)$ and it varied from $92.20 \mathrm{~g}$ to $135.90 \mathrm{~g}$ for fruit weight, $39.63 \mathrm{~g}$ to $81.53 \mathrm{~g}$ for peel weight, 52.57 to $108.80 \mathrm{~g}$ for pulp weight and 2.50 to $3.77 \mathrm{~cm}$ for pulp thickness respectively. Fruit length was maximum $(23.93 \mathrm{~cm})$ in Nendran $\left(\mathrm{V}_{4}\right)$ and minimum $(15.40)$ in Poyo $\left(\mathrm{V}_{4}\right)$ while the maximum fruit diameter $(4.25 \mathrm{~cm})$ was observed in Champa $\left(\mathrm{V}_{6}\right)$ and minimum $(2.80 \mathrm{~cm})$ in Poyo $\left(\mathrm{V}_{2}\right)$. Pulp to peel ratio was observed to be significantly higher in $\mathrm{V}_{4}$ i.e. 'Nendran'. Ease of peeling and TSS were recorded high Poyo $\left(\mathrm{V}_{2}\right)$. 


\section{REFERENCES}

1. Anonymous. (2002). Group Workers Meeting of AICRP on PHT of horticultural crops. Trial Data of 2000-2001 presented in Workshop held at Konkan Krishi Vidyapeeth, Dapoli from 5th to 7th March 2002.

2. Anonymous. (2015). Indian Horticulture Database, NHB. Aristo Printing Press, DDA Shed, Okhla Industrial Area, Phase-I, New Delhi, India, pp 34-41.

3. Belayneh, M., Workneh, T. S. and Belew, D. (2013). Physicochemical and sensory evaluation of some cooking banana (Musa spp.) for boiling and frying process. J. Food Sci. Technol., 51(12): 3635-3646.

4. Dadzie, B. K. and Orchard, J. E. (1997). Routine post-harvest screening of banana/plantain hybrids: criteria and methods. International Plant Genetic Resources Institute (IPGRI), Rome, Italy, pp 5-37.

5. Forster, M., Elena, R. R., Jacinto, D. M. and Carlos, D. R. (2003). Distribution of nutrients in edible banana pulp. Food Technol. Biotechnol., 41(2): 167-171.

6. Gomez, K. A. and Gomez, A. A. (1984). Statistical procedures for agricultural research, (2 ${ }^{\text {nd }}$ Edn.) John Wiley and Sons, New York.

7. Kundan, K., Pathak, K. A., Rohit, S. and Rinku, B. (2011). Effect of storage temperature on physico-chemical and sensory attributes of purple passion fruit (Passiflora edulis Sims). J. Food Sci. Technol., 48(4): 484-488.

8. Muchui, M. N., Njoroge, C. K., Kahangi, E. M., Onyango, C. A. (2010). Determination of maturity indices of tissue cultured bananas (Musa spp.) 'Williams' and 'Grande Naine'. Acta Hort., 879: 425-430.

9. Tigist, M., Workneh, T. S. and Woldetsadik, K. (2013). Effects of variety on the quality of tomato stored under ambient conditions. J. Food Sci. Technol., 50(3): 477-486. 
